\title{
KOMPOSISI UKURAN CAKALANG (Katsuwonus pelamis) HASIL TANGKAPAN HUHATE YANG DIDARATKAN DI TULEHU, AMBON
}

\author{
Budi Nugraha1), Siti Mardlijah"1), dan Enjah Rahmat ${ }^{2)}$ \\ 1) Peneliti pada Balai Riset Perikanan Laut, Muara Baru-Jakarta \\ 2) Teknisi Litkayasa pada Balai Riset Perikanan Laut, Muara Baru-Jakarta \\ Teregistrasi I tanggal: 27 September 2010; Diterima setelah perbaikan tanggal: 5 Nopember 2010; \\ Disetujui terbit tanggal: 15 Nopember 2010
}

\begin{abstract}
ABSTRAK
Eksploitasi sumber daya ikan cakalang (Katsuwonus pelamis) di perairan Laut Banda telah berlangsung lama. Saat ini sumber daya ikan cakalang telah memperlihatkan tanda-tanda overfishing. Indikasi ini antara lain ditandai oleh penurunan hasil tangkapan dan ukuran individu, perubahan komposisi hasil tangkapan, serta kecenderungan meningkatnya proporsi beberapa jenis ikan berukuran kecil. Data frekuensi panjang dikumpulkan dari bulan Maret sampai Desember 2007 berjumlah 4.293 ekor. Pengukuran panjang dan bobot untuk mengetahui hubungan panjang dan bobot ikan dilakukan pada bulan Maret, Mei, Juli, dan Desember 2007 dengan jumlah contoh 296 ekor. Tulisan ini menyajikan informasi tentang distribusi ukuran panjang dan bobot, hubungan panjang dan bobot ikan cakalang dan ukuran pertama kali tertangkap (LC) hasil tangkapan huhate yang beroperasi di perairan Laut Banda. Hasil analisis menunjukan bahwa ikan cakalang mempunyai kisaran panjang cagak (FL) antara 30-78 cmFL dan kisaran bobot antara 600-4300 g. Analisis regresi hubungan panjang dan bobot diperoleh persamaan $W=0,0485 L^{2,751}, R^{2}=0,9427$ dengan nilai koefisien regresi $(r)=0,9709$, dan nilai slope $(b)=2,751$. Dari hasil analisis tersebut diketahui bahwa pola pertumbuhan ikan cakalang bersifat allometrik negatif. Ukuran pertama kali tertangkap (Lc) ikan cakalang oleh huhate adalah 41,7 cmFL.
\end{abstract}

KATAKUNCl: $\quad$ komposisi ukuran, ikan cakalang, huhate, Ambon

ABSTRACT: $\quad$ Size composition of skipjack tuna (Katsuwonus pelamis) caught by pole and line landed in the tulehu, Ambon. By: Budi Nugraha, Siti Mardlijah, and Enjah Rahmat

Exploitation of skipjack tuna resources in the Banda Sea have lasted long. Currently skipjack tuna resources have been showing signs of over fishing. Indications were, among others, characterized by a decrease in the catch and the size of the individual, changes in the composition of the catch and the trend of increasing proportions of several types of small fish. Length frequency data collected from March until December 2007 amounted 4,293. Length and weight measurements to determine the length and weight relationship of fish conducted in March, May, July, and December 2007 with a total sample was 296. This paper presents information about the distribution of length and weight, length and weight relationship and the length at first capture $(L c)$ caught by pole and liner operating in the Banda Sea. The analysis showed that the skipjack tuna has a long range between 30-78 cmFL and weight range between 600-4300 g. Regression analysis of length and weight relationship equation was $W=0.0485 L^{2.751}, R^{2}=0.9427$ with regression coefficient $(r)=0.9709$, and slope value $(b)=2.751$. Result show that the growth pattern of skipjack tuna was negative allometric. The length at first captured (Lc) of skipjack was $41.7 \mathrm{cmFL}$.

\section{KEYWORDS: $\quad$ size composition, skipjack tuna, pole and line, Ambon}

\section{PENDAHULUAN}

Ikan cakalang atau dalam bahasa Inggris dikenal dengan skipjack tuna adalah salah satu ikan yang termasuk ke dalam famili Scombridae dan merupakan satu-satunya spesies dari genus Katsuwonus. Ikan cakalang hidup bergerombol dalam suatu kawanan yang berjumlah besar (dapat mencapai 50.000 ekor ikan). Ikan ini dikenal sebagai perenang cepat di laut daerah pelagis dan daerah penyebarannya terdapat di laut tropis dan sub tropis, antara lain di Samudera
Hindia, Samudera Pasifik, dan Samudera Atlantik. Ikan ini tidak ditemukan di utara Laut Tengah (Anonimus, 2010a). Daerah penyebaran di Indonesia meliputi Samudera Hindia (perairan barat Sumatera, selatan Jawa, Bali, dan Nusa Tenggara), perairan Indonesia bagian timur (Laut Sulawesi, Maluku, Arafuru, Banda, Flores, dan Selat Makassar) dan Samudera Pasifik (perairan utara Irian Jaya) (Uktolseja et al., 1989 dalam Rukka, 2006). Menurut Anonimus (2010b) daerah penangkapan ikan cakalang di dunia terdiri atas 55\% di Samudera Pasifik sebelah barat, $12 \%$ di Samudera 
Pasifik sebelah timur, dan 20\% di Samudera Hindia. Ikan ini pada umumnya tertangkap oleh alat tangkap pukat cincin (purse seine).

Penangkapan ikan cakalang relatif stabil pada awal tahun 1990-an yaitu sekitar 1.000 .000 ton, namun terus meningkat mencapai 1.500 .000 ton pada tahun 2006 di Samudera Pasifik bagian barat dan tengah (Langley \& Hampton, 2008). Total hasil tangkapan ikan cakalang yang dikatakan kepada FAO pada tahun 1999 sebesar 1.976 .479 ton. Selain Jepang, negara yang paling banyak menangkap ikan cakalang adalah Indonesia, yaitu 205.670 ton (FAO, 2010). Panjang maksimum FL ikan cakalang sekitar $108 \mathrm{~cm}$ dengan bobot $32,5-34,5 \mathrm{~kg}$, namun saat ini pada umumnya panjang ikan cakalang sekitar $35 \mathrm{cmFL}$ dengan bobot $3 \mathrm{~kg}$ (Anonimus, 2010b).

Ambon merupakan salah satu sentra perikanan di Kawasan Timur Indonesia selain Bitung, Kendari, Ternate, dan Sorong. Armada penangkapan yang khusus menangkap ikan cakalang di Ambon didominansi oleh huhate (pole and line) dan pancing tonda (troll line). Pelabuhan Tulehu merupakan basis perikanan huhate di Ambon dengan hasil tangkapan didominansi oleh ikan cakalang yang ditangkap dari Laut Banda. Informasi tentang komposisi hasil tangkapan dan aspek biologi (ukuran panjang dan bobot) di perairan Laut Banda dan didaratkan di Tulehu belum banyak diperoleh. Tulisan ini menyajikan informasi tentang distribusi ukuran panjang dan bobot, hubungan panjang dan bobot ikan cakalang dan ukuran pertama kali tertangkap (Lc) hasil tangkapan huhate yang beroperasi di perairan Laut Banda.

\section{BAHAN DAN METODE}

Pengumpulan data dilakukan di Tulehu, Ambon selama tahun 2007. Jenis data yang dikumpulkan adalah data operasional penangkapan yaitu deskripsi alat tangkap, daerah penangkapan dan komposisi hasil tangkapan, serta data biologi yaitu frekuensi ukuran panjang dan bobot.

Data operasional penangkapan diperoleh dengan cara wawancara dan mengikuti kegiatan penangkapan kapal huhate yang berbasis di Tulehu. Data biologi diperoleh dari hasil pengukuran yang dilakukan oleh peneliti dan enumerator di lapangan. Data frekuensi panjang individu yang dikumpulkan dari bulan Maret sampai Desember 2007 berjumlah 4.293 ekor. Pengukuran panjang dan bobot dilakukan pada bulan Maret, Mei, Juli, dan Desember 2007 dengan jumlah contoh 296 ekor.
Pendugaan ukuran ikan pertama kali tertangkap menggunakan persamaan Kerstan (1985), yaitu:

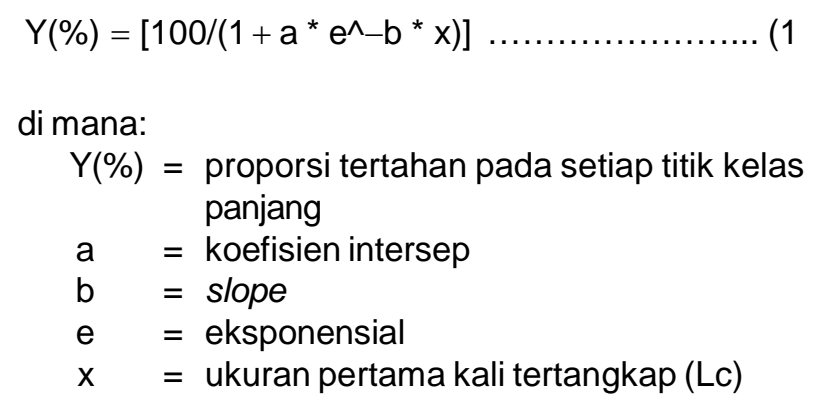

Untuk mengetahui hubungan panjang dan bobot digunakan rumus Bal \& Rao (1984), yaitu:

$$
W=a L^{b}
$$

di mana:

$$
\begin{array}{ll}
\mathrm{W} & =\text { bobot ikan }(\mathrm{g}) \\
\mathrm{L} & =\text { panjang ikan }(\mathrm{cmFL}) \\
\mathrm{a} \text { dan } \mathrm{b} & =\text { konstanta }
\end{array}
$$

Nilai $b$ digunakan sebagai penduga tingkat kedekatan hubungan antara panjang dan bobot dengan hukum kubik:

1. Nilai $b=3$, merupakan hubungan yang isometrik (pertambahan bobot seimbang dengan pertambahan panjang pangkat tiga, atau dengan kata lain mengikuti hukum kubik).

2. Nilai $b>3$, merupakan hubungan allometrik positif (pertambahan bobot lebih besar dari pertambahan panjang pangkat tiga).

3. Nilai $b<3$, merupakan hubungan allometrik negatif (pertambahan bobot lebih kecil dari pertambahan panjang pangkat tiga).

\section{HASIL DAN BAHASAN}

\section{Aspek Operasional dan Deskripsi Alat Tangkap}

Tulehu merupakan basis perikanan huhate di Ambon. Pada saat ini ada sekitar 11 kapal huhate yang aktif dan berbasis di Tulehu dan sekitarnya. Kapal terbuat dari kayu dan fiber glass berukuran 15-30 GT dengan tenaga penggerak berkisar antara 115-165 PK. Palka untuk menyimpan umpan berjumlah tiga buah, sedangkan palka untuk menyimpan hasil tangkapan berjumlah antara 6-7 buah dengan volume berkisar 2 ton (Gambar 1). Anak buah kapal kapal huhate berjumlah 20-25 orang, terdiri atas nakhoda (kapten), juru mudi, motoris, penjaga sirkulasi udara untuk umpan, penebar umpan, dan pemancing. 


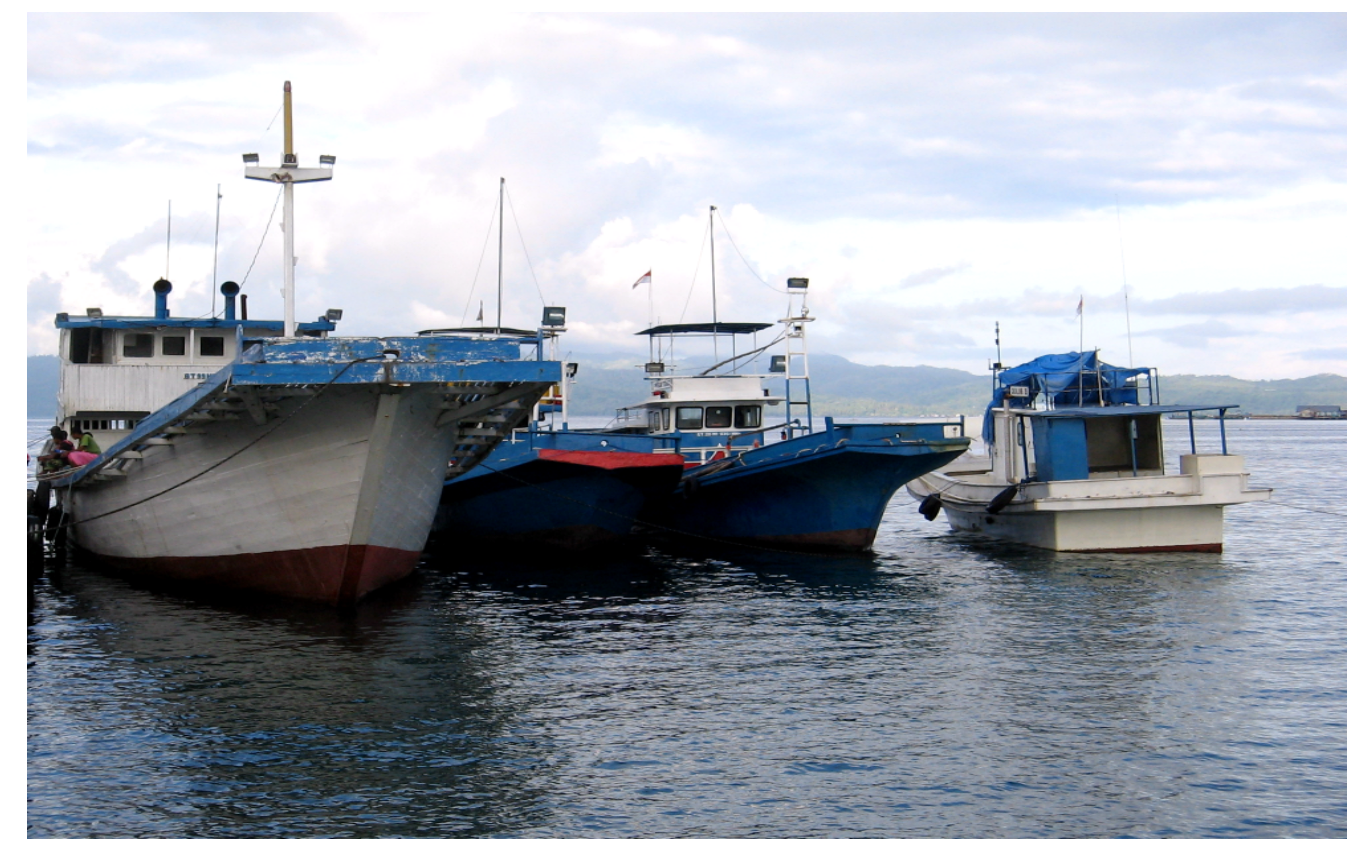

Gambar 1. Kapal huhate yang berbasis di Tulehu, Ambon.

Figure 1. Pole and liner based on Tulehu, Ambon.

Deskripsi huhate yang dipergunakan oleh nelayan Tulehu, Ambon terdiri atas joran atau bambu berdiameter $3 \mathrm{~cm}$, panjang tali $85 \mathrm{~cm}$ terbuat dari tambang plastik, mata pancing nomor 15 dan tidak berkait. Untuk menarik ikan sasaran, pada bagian atas mata pancing dibungkus dengan kain warna-warni dari bahan sifon. Ikan umpan hidup yang digunakan adalah jenis ikan teri (Stolephorus sp.), layang (Decapterus sp.), lemuru (Sardinella sp.), dan kembung (Rastreligersp.). Konstruksi pancing huhate disajikan pada Gambar 2.

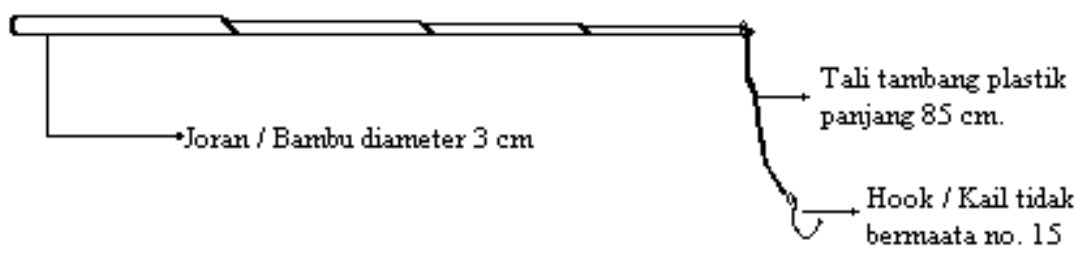

Gambar 2.

Konstruksi pancing huhate yang digunakan nelayan Tulehu, Ambon.

Figure 2.

The construction of pole and line used by fisherman of Tulehu, Ambon.

Operasi penangkapan berlangsung selama 1-12 hari per trip dengan daerah penangkapan di perairan Laut Banda dan sekitarnya (Gambar 3). Aktivitas penangkapan dilakukan di sekitar rumpon. Nelayan Tulehu dan sekitarnya mempunyai dua unit rumpon yang telah dipasang di perairan Laut Banda yaitu di sekitar Pulau Molana dan Pulau Laut yang masing- masing berjarak sekitar 22 dan 40 mil dari Tulehu. Terdapat dua unit rumpon lain yang menjadi daerah penangkapan yaitu di perairan sekitar Pulau Ambelau yang berjarak sekitar 78 dan 89 mil dari Tulehu. Bila di sekitar rumpon tidak ada ikan, penangkapan ikan dilakukan pada kawanan ikan (schooling) di luar rumpon. 


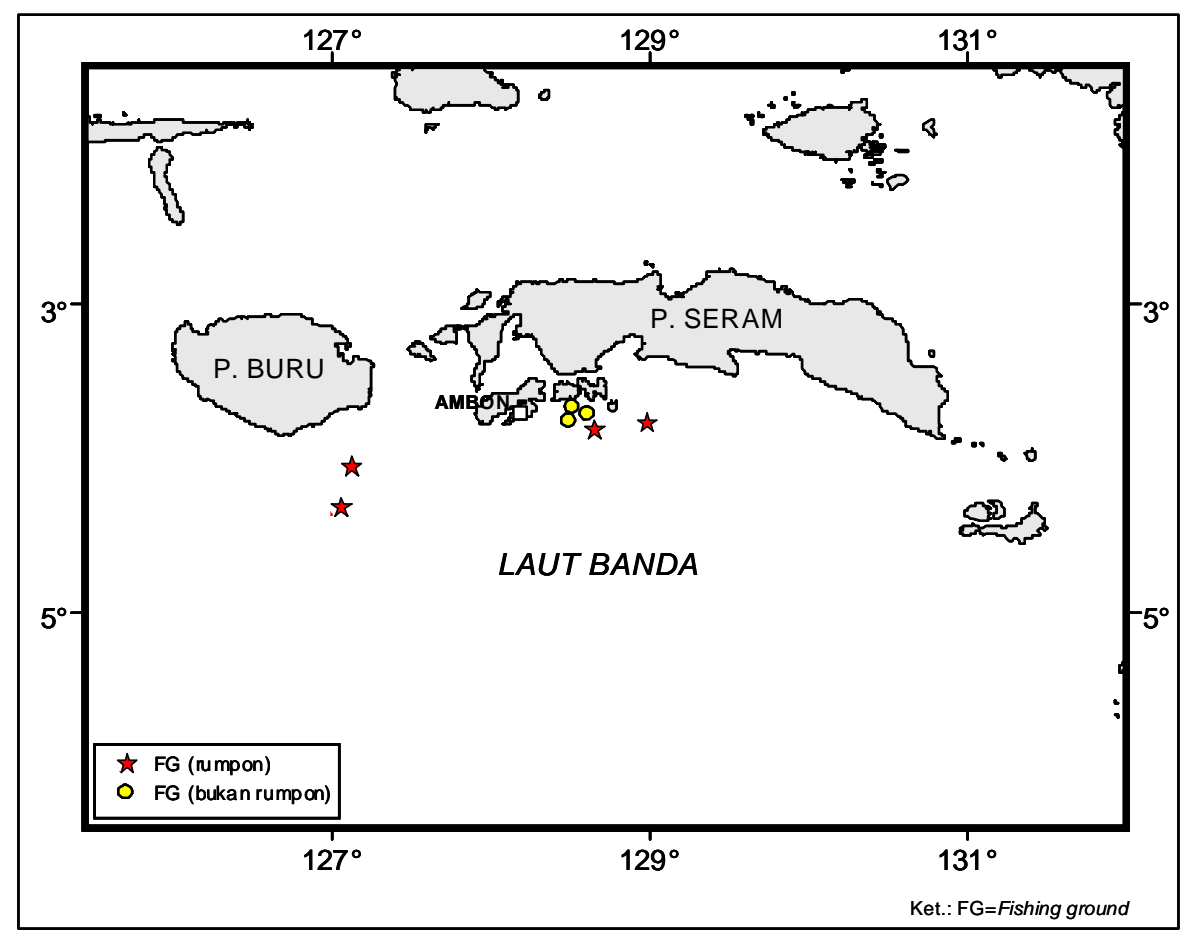

Gambar 3.

Figure 3.

Daerah penangkapan kapal huhate yang berbasis di Tulehu, Ambon.

Fishing ground of pole and liner based on Tulehu, Ambon.

Berdasarkan atas hasil observasi yang dilakukan dengan mengikuti kegiatan penangkapan kapal huhate di Laut Banda pada bulan Juli 2007 diperoleh hasil tangkapan ikan cakalang, baby tuna yang terdiri atas ikan tuna mata besar (Thunnus obesus) dan madidihang (Thunnus albacares) dan jenis-jenis ikan tongkol (Auxis sp. dan Euthynnus sp.) (Gambar 4). Menurut nelayan musim ikan berlangsung antara bulan Juli sampai Agustus, sedangkan musim sedikit tangkapan berlangsung antara bulan Nopember sampai Desember.

\section{E. lineatus}

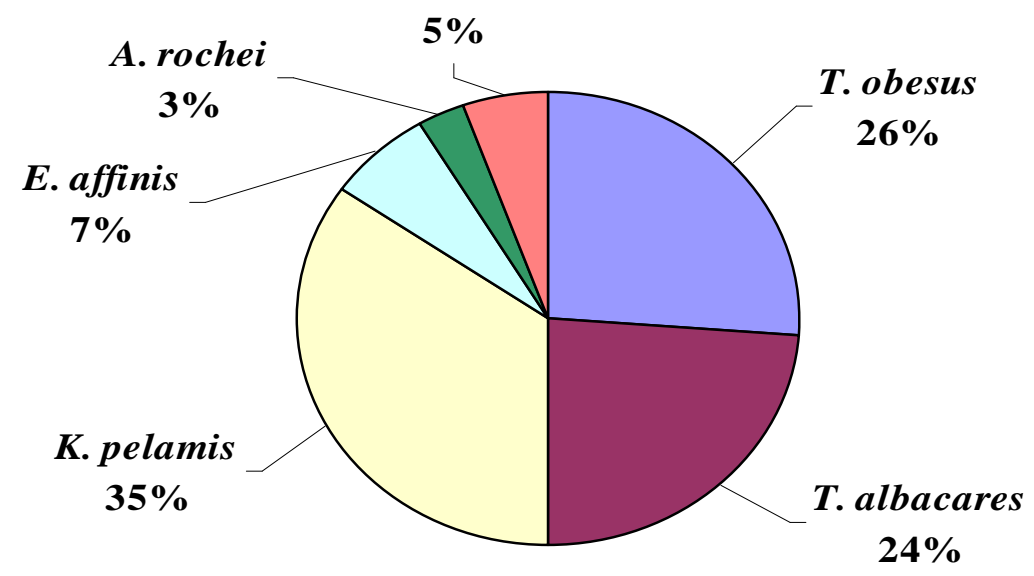

Gambar 4. Komposisi hasil tangkapan kapal huhate, bulan Juli 2007.

Figure 4. Catch composition of pole and liner, July 2007. 


\section{Komposisi Ukuran Cakalang}

Pengukuran panjang cagak (FL) ikan cakalang pada bulan Maret sampai Desember 2007 diperoleh kisaran antara 30-78 cmFL dengan panjang maksimal $78 \mathrm{cmFL}$ (Gambar 5). Bobot ikan cakalang mempunyai kisaran antara 600-4.300 g dengan bobot maksimal $4.300 \mathrm{~g}$ (Gambar 6).
Panjang cagak rata-rata ikan cakalang yang didaratkan di Tulehu, Ambon dari bulan Maret sampai Juli menunjukan ukuran ikan yang tertangkap semakin besar (Tabel 1). Hal ini diduga bahwa ikan cakalang yang tertangkap telah mendekati matang gonad. Hasil penelitian Sumadhiharga \& Hukom (1989) mengatakan bahwa puncak musim pemijahan ikan cakalang di Laut Banda diduga pada bulan Juni dan Desember dengan musim pemijahan sepanjang tahun.

Tabel 1. Hasil pengamatan distribusi panjang cagak ikan cakalang

Table 1. The observation on distribution of tuna long forked

\begin{tabular}{lcccc}
\hline $\begin{array}{c}\text { Bulan/ } \\
\text { Month }\end{array}$ & $\begin{array}{c}\text { Jumlah contoh/ } \\
\text { Total sample } \\
\text { (ekor) }\end{array}$ & $\begin{array}{c}\text { Panjang maksimum/ } \\
\text { Maximum length } \\
\text { (cm) }\end{array}$ & $\begin{array}{c}\text { Panjang minimum/ } \\
\text { Minimum length } \\
\text { (cm) }\end{array}$ & $\begin{array}{c}\text { Panjang rata-rata/ } \\
\text { The average length } \\
\text { (cm) }\end{array}$ \\
\hline Maret & 95 & 38 & 30 & 32,96 \\
April & 816 & 33 & 30 & 31,54 \\
Mei & 722 & 55 & 30 & 41,81 \\
Juni & 975 & 55 & 30 & 44,45 \\
Juli & 925 & 78 & 32 & 50,75 \\
Agustus & 170 & 56 & 30 & 40,62 \\
September & 150 & 54 & 30 & 41,04 \\
Oktober & 170 & 55 & 30 & 40,52 \\
Nopember & 160 & 55 & 30 & 40,78 \\
Desember & 110 & 55 & 30 & 41,02 \\
\hline
\end{tabular}
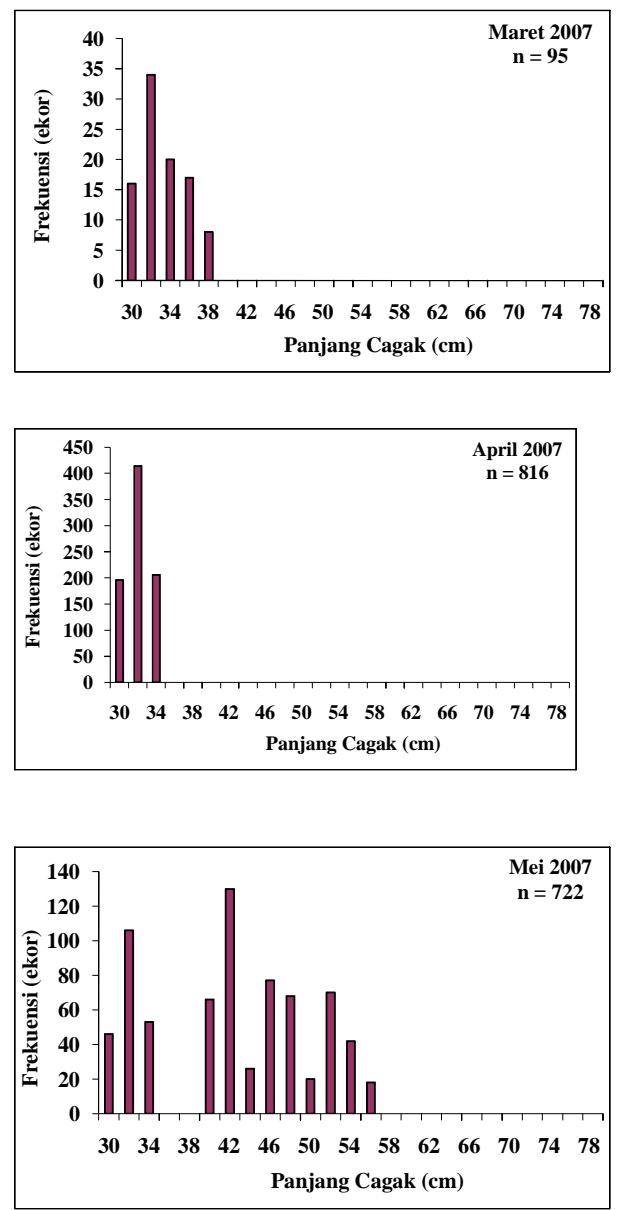
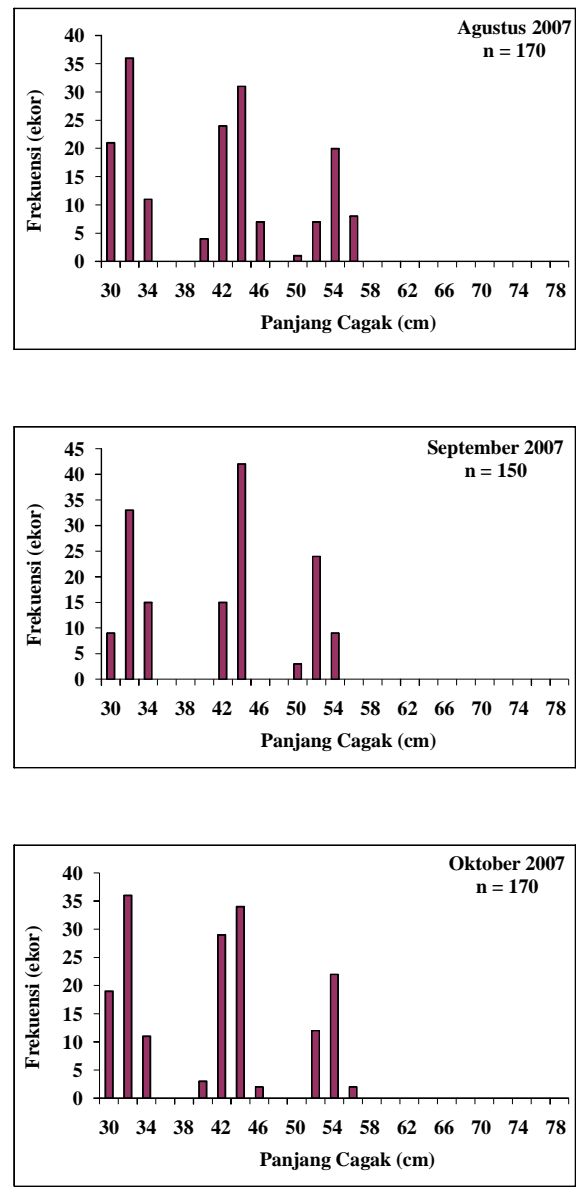

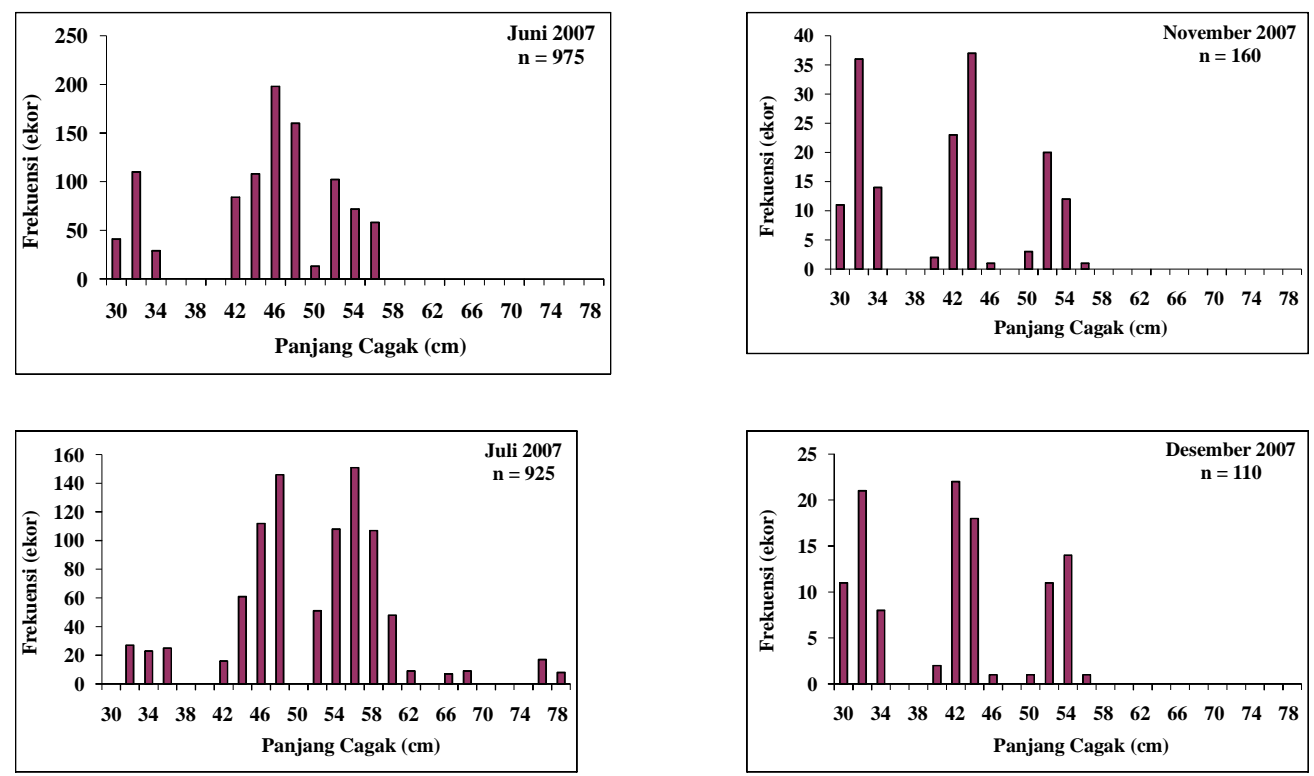

Gambar 5. Distribusi frekuensi panjang cagak ikan cakalang hasil tangkapan huhate yang didaratkan di Tulehu, bulan Maret sampai Desember 2007.

Figure 5. Length frequency distribution of skipjack tuna caught by pole and line landed at Tulehu, March until December 2007.
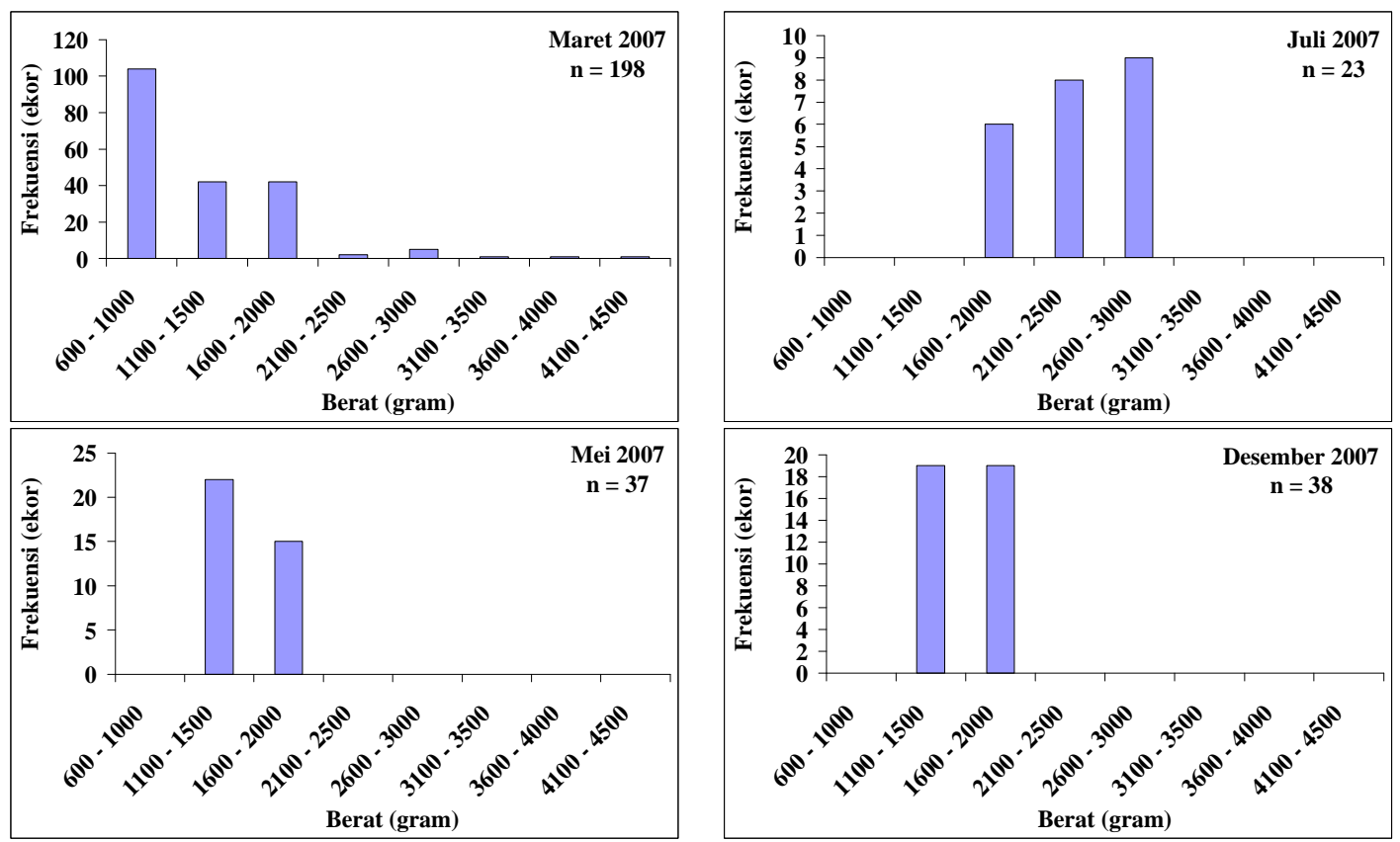

Gambar 6. Distribusi frekuensi bobot ikan cakalang hasil tangkapan huhate yang didaratkan di Tulehu pada bulan Maret, Mei, Juli, dan Desember 2007.

Figure 6. Weight frequency distribution of skipjack tuna caught by pole and liner landed at Tulehu in March, May, July, and December 2007. 
Hasil pengukuran terhadap panjang ikan cakalang menunjukan bahwa sekitar $31,4 \%$ mempunyai panjang kurang dari $35 \mathrm{cmFL}$ dan $68,6 \%$ mempunyai panjang lebih dari $35 \mathrm{cmFL}$, sedangkan bobotnya menunjukan 99,0\% kurang dari $3 \mathrm{~kg}$. Dengan demikian, ikan cakalang yang tertangkap oleh huhate di perairan Laut Banda dan didaratkan di Tulehu mempunyai ukuran tubuh yang panjang namun memiliki bobot yang relatif kecil.

\section{Hubungan Panjang dan Bobot}

Analisis regresi antara panjang dan bobot ikan cakalang yang didaratkan di Tulehu diperoleh persamaan $W=0,0485 L^{2,751}, R^{2} 0,9427$ dengan nilai koefisien regresi $(r)=0,9709$ dan slope $(b)=2,751$ (Gambar 7). Hasil pengujian nilai b yang diperoleh terhadap nilai 3 pada taraf 95 dan $99 \%$ ikan cakalang diperoleh nilai $b<3$. Berdasarkan atas hukum kubik (Bal \& Rao, 1984), di mana nilai $b<3$ maka pola pertumbuhan ikan cakalang di Laut Banda bersifat allometrik negatif, menunjukan bahwa pertambahan panjang lebih cepat daripada pertambahan bobot.

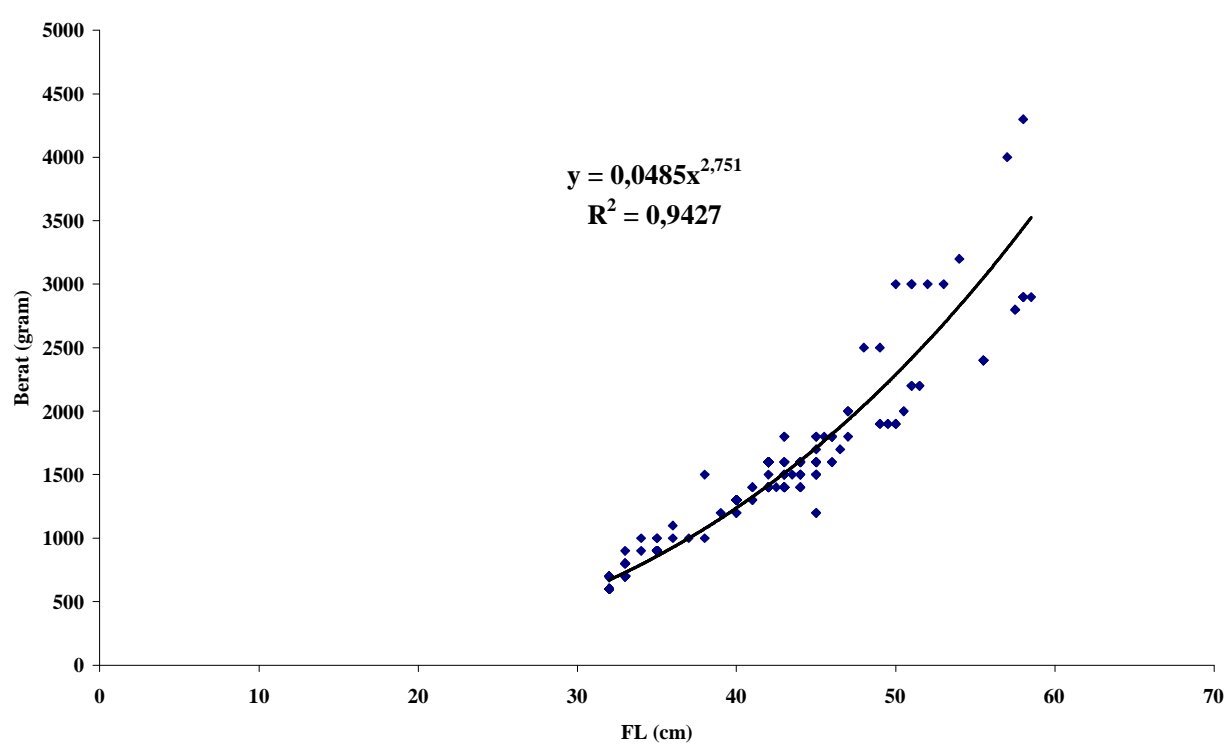

Gambar 7. Hubungan panjang dan bobot ikan cakalang hasil tangkapan huhate yang didaratkan di Tulehu, tahun 2007.

Figure 7. Length and weight relationship of skipjack tuna caught by pole and line was landed at Tulehu, 2007.

Pertumbuhan ikan cakalang di perairan Laut Banda tidak sama dengan pertumbuhan ikan cakalang di perairan Samudera Hindia bagian timur. Pokapunt et al. (1999) mengatakan bahwa ikan cakalang hasil tangkapan purse seine di perairan Samudera Hindia bagian timur bersifat allometrik positif. Berdasarkan atas informasi tersebut, dapat dikatakan bahwa ikan cakalang di perairan Laut Banda mempunyai ukuran lebih panjang dibandingkan ikan cakalang di perairan Samudera Hindia bagian timur.

\section{Ukuran Ikan Pertama Kali Tertangkap}

Hasil perhitungan diperoleh ukuran pertama kali tertangkap ikan cakalang oleh huhate berukuran 41,7 cmFL (Gambar 8). Menurut (Wade, 1950 dalam Wild \& Hampton, 1994) ukuran pertama kali matang gonad ikan cakalang (length at first maturity) di perairan Philipina pada panjang 40,9 cmFL. Ikan cakalang yang tertangkap dengan ukuran lebih dari $40,9 \mathrm{cmFL}$ sekitar $57,3 \%$. Dengan demikian, ikan cakalang yang tertangkap oleh huhate didominansi oleh ikan yang pernah mengalami matang gonad atau pernah melakukan pemijahan (spawning). 


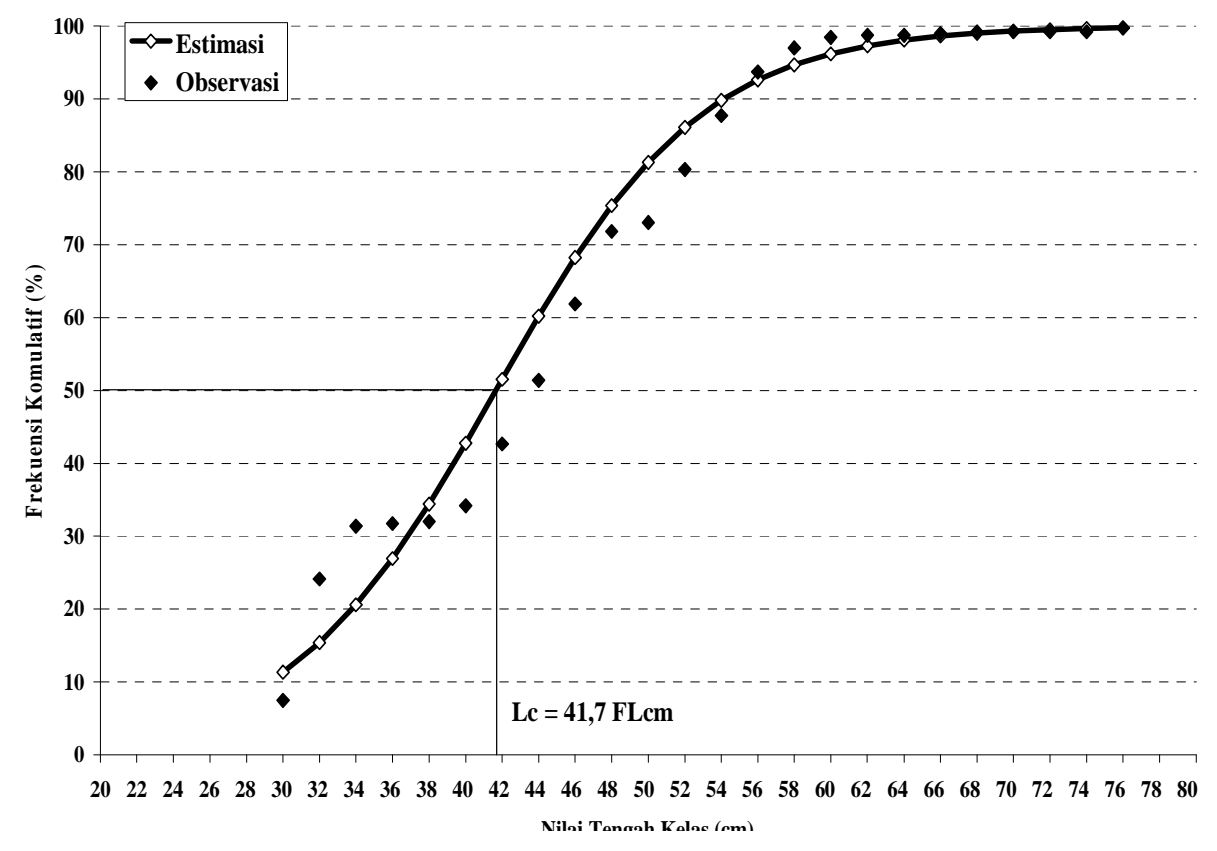

Gambar 8. Ukuran pertama kali tertangkap ikan cakalang oleh huhate dari Laut Banda yang didaratkan di Tulehu, tahun 2007.

Figure 8. Length at first capture of skipjack tuna caught by pole and line from Banda Sea was landed at Tulehu, 2007.

\section{KESIMPULAN}

1. Ikan cakalang yang tertangkap oleh huhate di perairan Laut Banda dan didaratkan di Tulehu mempunyai ukuran tubuh yang panjang namun memiliki bobot yang relatif kecil.

2. Hubungan panjang dan bobot ikan cakalang diperoleh persamaan $\mathrm{W}=0,0485 \mathrm{~L}^{2,751}$, dengan nilai $r=0,9709$ dan $b=2,751$.

3. Ikan cakalang yang tertangkap oleh huhate didominansi oleh ikan cakalang yang pernah mengalami matang gonad atau pernah melakukan pemijahan.

4. Ikan cakalang mempunyai pola pertumbuhan allometrik negatif.

5. Panjang pertama kali tertangkap dengan huhate $41,7 \mathrm{cmFL}$.

\section{PERSANTUNAN}

Tulisan ini merupakan kontribusi dari kegiatan hasil riset stok sumber daya ikan dan kondisi hidrologi perairan Laut Banda, T. A. 2007, di Balai Riset Perikanan Laut-Muara Baru, Jakarta.

\section{DAFTAR PUSTAKA}

Anonimus. 2010a. Cakalang. http://id.wikipedia.org/ wiki/Cakalang. Diunduh pada Tanggal 14 April 2010.

Anonimus. 2010b. Tuna Species. http:// www.sustunable.com/species.html. Diunduh pada Tanggal 16 April 2010.

Bal, D. V. \& K. V. Rao. 1984. Marine Fisheries. Tata Mc. Graw-Hill Publishing Company Limited. New Delhi. 5-24.

FAO. 2010. Katsuwonus pelamis (Linnaeus, 1758). FAO Fisheries and Aquaculture Department. http:/ /www.fao.org/fishery/species/2494/en. Diunduh pada Tanggal 24 Mei 2010.

Kerstan, M. 1985. Age, growth, maturity, and mortality estimates of horse mackerel (Trachurus trachurus) from the waters west of Great Britain and Ireland in 1984. Arch. FischWiss. 36 (1/2): 115-154.

Langley, A. \& J. Hampton. 2008. Stock assessment of skipjack tuna in the Western and Central Pacific Ocean. WCPFC Scientific Committee Fourth Regular Session, 11-22 August 2008, Port Moresby, Papua New Guinea. http://www.wcpfc.int. Diunduh pada Tanggal 21 Mei 2010. 
Pokapunt, W., V. Sornvijit \& N. Thongyou. 1999. Tuna caught by purse seining in the Eastern Indian Ocean. IOTC Proceedings. 2: 144-146. ftp:// ftp.fao.org/fi/cdrom/iotcproceedings(1999-2002)/ files/proceedings/proceedings2/wptt/TT99-02.pdf. Diunduh pada Tanggal 16 April 2010.

Rukka, A. H. 2006. Teknologi penangkapan pilihan untuk ikan cakalang di perairan Selayar Provinsi, Sulawesi Selatan. Tesis. (Tidak Dipublikasikan). Program Pascasarjana. Institut Pertanian Bogor. Bogor.

Sumadhiharga, K. \& F. D. Hukom. 1989. Hubungan panjang dan bobot, makanan dan reproduksi ikan cakalang (Katsuwonus pelamis) di Laut Banda dalam perairan Maluku dan sekitarnya. Biologi, Budi Daya, Geologi, Lingkungan, dan Oseanografi.Balai Penelitian dan Pengembangan Sumber Daya Laut. Pusat Penelitian dan Pengembangan Oseanologi. Lembaga IImu Pengetahuan Indonesia. Ambon. www.coremap.or.id/downloads/1235.pdf. Diunduh pada Tanggal 25 Mei 2010.

Wild, A. \& J. Hampton. 1994. A review of the biology and fisheries for skipjack tuna, Katsuwonus pelamis, in the Pacific Ocean. In Interactions of pacific tuna fisheries, R. S. Shomura, J. Majkowski, and S. Langi, eds. FAO Fish. Tech. Pap. 336/2:1-51. 